\title{
Et nyfødt barn med petekkier
}

\author{
Akutt sykdom hos nyfødte krever rask og korrekt behandling. Visse \\ sykdommer i nyfødtperioden er forbundet med svært høy gjentakelses- \\ risiko ved kvinnens senere svangerskap og fødsler. I slike tilfeller må \\ man vurdere målrettede forebyggende tiltak.
}

To friske, ubeslektede foreldre fikk sitt første barn etter et ukomplisert svangerskap. Fødselen skjedde ved svangerskapslengde 39 uker og to dager. Barnet ble født etter akutt keisersnitt pga. occiput posterior, langtrukket fødselsforløp og risvekkelse. Barnet var slapt og blekt ved fødselen, veide $2740 \mathrm{~g}$ og fikk apgarskår 2, 6, 7 etter henholdsvis ett, fem og ti minutter. På grunn av respiratorisk besvær ble hun ventilert ved hjelp av maske og bag de første tre minuttene, deretter med Neopuff (maske-CPAP) i 15 minutter. Det ble observert multiple petekkiale hudblødninger samt hematomforandringer over caput like etter fødselen. Hematologiske prøver viste alvorlig trombocytopeni - $9 \cdot 10^{9}$ celler $/ \mathrm{l}\left(145-390 \cdot 10^{9} \mathrm{cel}\right.$ ler/l). Det ble gitt bestrålt trombocyttkonsentrat fra fire tilfeldige givere $(15 \mathrm{ml} / \mathrm{kg})$, intravenøs injeksjon av polyklonalt immunglobulin (IVlg) på 0,8 g/kg samt K-vitamin peroralt. Cerebral ultralyd viste parenkymatøs blødning medialt i parietalcortex bilateralt. For nærmere kartlegging ble det utført MR caput, som avdekket bilaterale kortikale og epidurale blødninger (fig 1). Disse ble tolket som ferske. Nevrokirurg anbefalte videre observasjon og konservativ behandling.

Trombocytopeni påvises hos om lag $1 \%$ av alle nyfødte (1-3). Det er vanlig å dele årsakene inn i hovedkategoriene redusert produksjon eller økt destruksjon. Årsaker til redusert produksjon kan være arvelig trombocytopeni, infeksjoner (bakterier, virus, sopp) og toksisk beinmargspåvirkning grunnet legemiddelbruk hos moren. Økt destruksjon kan skyldes immunologiske forhold (auto- eller alloantistoffer), perifert forbruk (hypersplenisme, Kasabach-Merritts syndrom, disseminert intravasal koagulasjon (DIC)) og iatrogene forhold (f.eks. utskiftningstransfusjon). Korrekt diagnose stilles ved hjelp av morens og barnets sykehistorie, grundig klinisk unders $\varnothing$ kelse av barnet og laboratorieunders $\varnothing$ kelser. Ved alvorlig trombocytopeni, definert som konsentrasjon lavere enn $50 \cdot 10^{9}$ celler/l, foreligger det som oftest alloantistoffmediert trombocytopeni (4).

Trombocyttene har mange ulike trombocyttspesifikke antigener (human platelet antigen, HPA) på overflaten, og det er identifisert 13 biallele HPA-systemer. De to allelene i hvert system benevnes $a$ og $b-a$ er hyppig og $b$ sjeldent forekommende $(5,6)$. HPA-1a-antigenet er det viktigste i forbindelse med føtal/neonatal alloimmun trombocytopeni (FNAIT). $98 \%$ av alle kaukasiere har HPA-1a-antigenet i enten dobbel (homozygot) eller enkel (heterozygot) utgave, de resterende $2 \%$ er homozygote for HPA-1b-antigenet - fenotypen er altså HPA$1 \mathrm{bb}$ (4). Alloimmunisering med HPA-antigenene kan skje ved uforlikelige svangerskap og, sjeldnere, i forbindelse med transfusjoner.

Barnets alvorlige medfødte trombocytopeni ga mistanke om antistoffmediert nedbrytning av trombocytter. Det ble derfor tatt blodprøver av foreldre og barn til trombocyttyping og antistoffundersøkelse. Etter transfusjon med trombocytter fra tilfeldig valgte givere var det en beskjeden stigning i trombocyttallet til 22-24. $10^{9}$ celler/l. Det ble gitt ytterligere to trombocyttransfusjoner, med påfølgende sparsom stigning i trombocyttallet. HPA-1a-negativt trombocyttkonsentrat ble oversendt fra blodbanken ved Oslo universitetssykehus, Ullevål, og transfundert til barnet $i$ løpet av tredje levedøgn. Trombocyttverdien steg da til $124 \cdot 10^{9}$ celler/l. Trombocyttstigningen var nå klart tydeligere enn ved de foregående transfusjonene fra tilfeldig valgte givere. Dette styrket mistanken om at det forelå føtal/neonatal alloimmun trombocytopeni. Imidlertid falt trombocyttallet gradvis i løpet av de neste 2-3 dagene. Barnet fikk derfor ytterligere to transfusjoner med trombocytter av HPA-1anegativt trombocyttkonsentrat og ytterligere én dose immunglobulin intravenøst i løpet av 4.-6. levedøgn.

Da barnet var i sitt 5. levedøgn, forelå det svar på trombocyttypingen. Den viste at moren hadde blodplatetypen HPA-1bb, barnet HPA-1ab og faren HPA-1ab. I morens plasma ble det påvist antistoff med spesifisiteten anti-HPA-1a. Diagnosen føtal/neonatal alloimmun trombocytopeni ble dermed bekreftet. Til tross for transfusjoner med forlikelige trombocytter ble det ikke noen varig normali-

\section{Beate Horsberg Eriksen \\ beate.h.eriksen@ntnu.no \\ Barne- og ungdomsavdelingen \\ Ålesund sykehus}

\section{Anne Husebekk}

Institutt for medisinsk biologi

Det helsevitenskapelige fakultet Universitetet i Tromsø

og

Avdeling for laboratoriemedisin Universitetssykehuset Nord-Norge

\section{Drude Fugelseth}

Nyfødtintensiv avdeling Oslo universitetssykehus, Ullevål og

Institutt for klinisk medisin

Universitetet i Oslo

\section{Karen Reistad Salberg}

Røntgenavdelingen

Ålesund sykehus

\section{Rolf Lindemann}

Nyfødtintensiv avdeling

Oslo universitetssykehus, Ullevål

og

Institutt for klinisk medisin

Universitetet i Oslo

Se kommentar på side 764

Engelsk oversettelse på www.tidsskriftet.no 


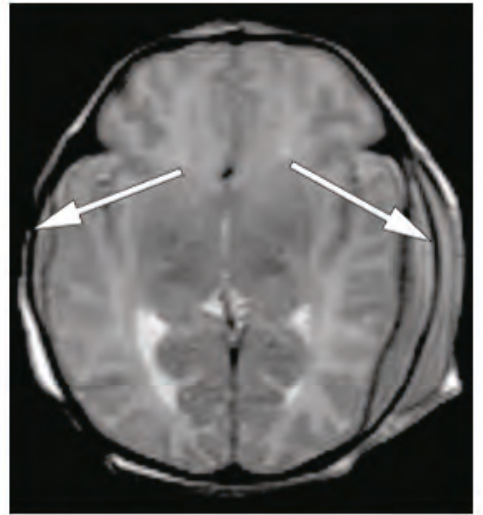

a
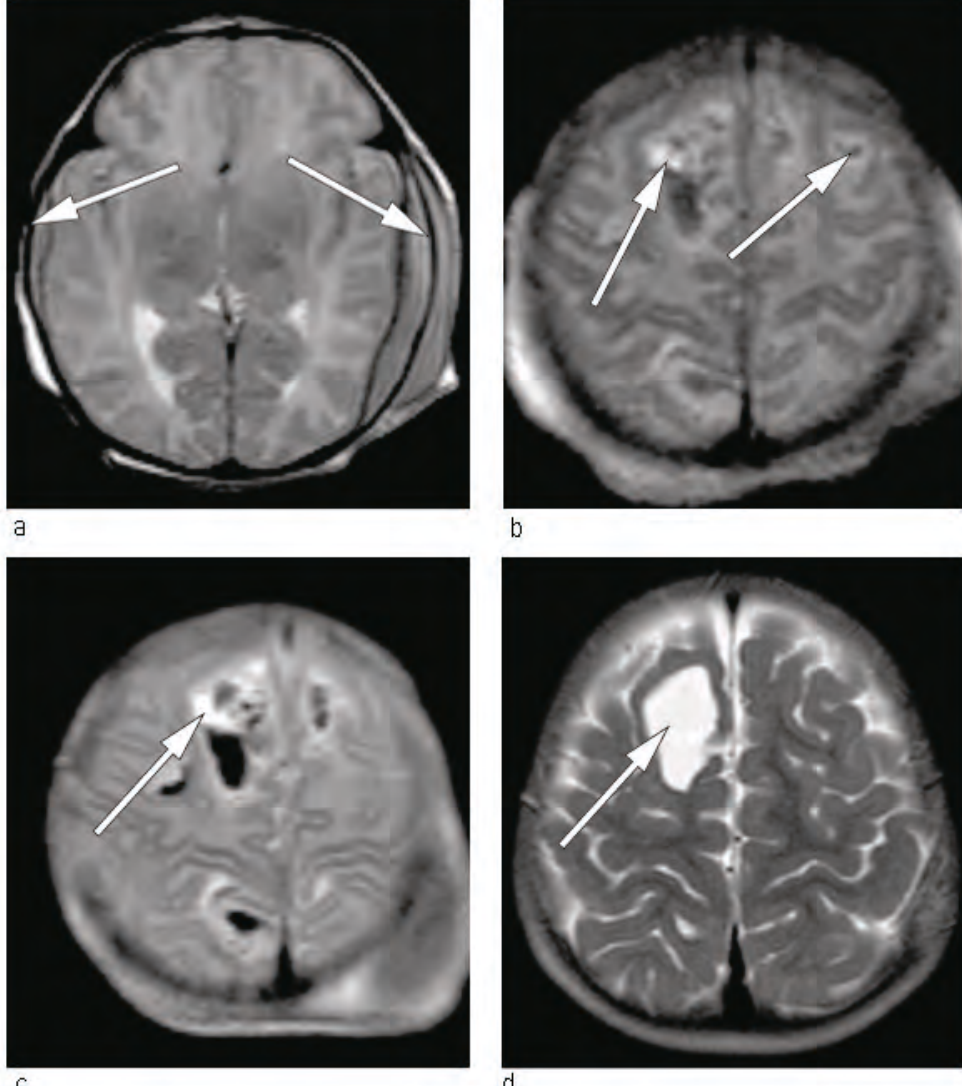

b

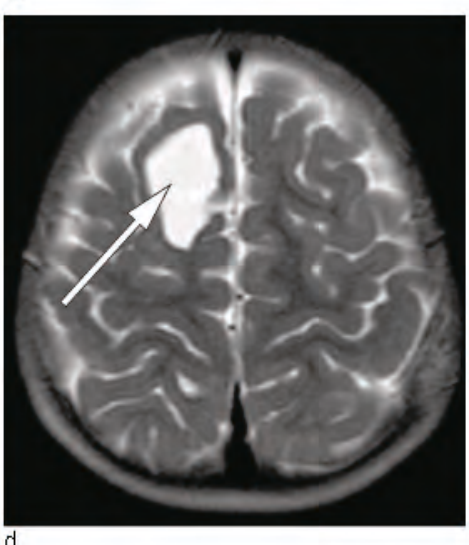

Figur 1 MR caput, T2-opptak med 1,5 tesla-maskin. Bildeopptak første levedøgn viser al ferske subdurale hematomer (piler) og b) blanding av ferske og 3-4 dager gamle intracerebrale hematomer (piler). c) Kontroll etter ett døgn viser størrelsesøkning av det ene intracerebrale hematomet (pil). d) Etter 15 måneder er det et gjenværende hulrom frontalt etter det største intracerebrale hematomet (pil)

sering av trombocyttallet de første dagene. Den fjerde dosen med forlikelige trombocytter ble transfundert til barnet da det var sju dager gammelt. Det ble da observert en stigning i trombocyttallet fra $72 \cdot 10^{9}$ celler/l til $216 \cdot 10^{9}$ celler/l. Imidlertid så man igjen gradvis fallende trombocyttverdier - fra $216 \cdot 10^{9}$ celler/l til $63 \cdot 10^{9}$ celler/l i lopet av de neste fire dagene.

Kvinner med trombocyttfenotype HPA-1bb kan danne alloantistoff mot HPA-1a i løpet av graviditeten dersom fosteret har arvet HPA1a-antigenet fra faren. De maternelle alloantistoffene er av IgG-type, kan passere placenta og feste seg til overflaten av fosterets blodplater, som deretter destrueres. Kvinnen vil ha normalt trombocyttall og kan immuniseres i første svangerskap (25\%) eller i forbindelse med forløsningen (75\%). Dermed kan fosteret være affisert i første svangerskap (7). Dette står i kontrast til antistoffmediert hemolytisk sykdom hos nyfødte, der problemet sjelden oppstår i første svangerskap, men oftest i påfølgende uforlikelige svangerskap etter immunisering.

Ved føtal/neonatal alloimmun trombocytopeni kan fosteret få alvorlig trombocytopeni og blødninger allerede in utero $(5$, $6)$. I litteraturen angis insidensen til én per
1 000-2 $000(8,9)$. Dette innebærer at $\mathrm{i}$ Norge blir 30-60 nyfødte rammet hvert år. I de fleste tilfeller er ikke tilstanden forbundet med alvorlige blødningskomplikasjoner, men intrakranial blødning opptrer i $7-26 \%$ av tilfellene, med neonatal død som følge hos omtrent en tredel av disse (8).

For å hemme videre antistoffmediert trombocyttnedbrytning ble det utført utskiftningstransfusjon da barnet var ti dager gammelt. Det ble gitt HPA-1bb-trombocyttkonsentrat og immunglobulin intravenøst umiddelbart etter utskiftningstranfusjonen. Første trombocyttverdi etter fullført prosedyre var $249.10^{9}$ celler/l. I løpet av de neste fem dagene falt trombocyttallet igjen gradvis til $98 \cdot 10^{9}$ celler/l, og siste rest av forlikelige trombocytter ble gitt. Trombocyttverdien steg da til $136 \cdot 10^{9}$ celler/l og lå etter dette stabilt over $100 \cdot 10^{9}$ celler $/$ l.

Etter utskrivning ble barnet fulgt med blodprøver, først hver måned og deretter annenhver måned $i$ et halvt år. Trombocyttverdiene lå hele tiden innenfor normalområdet (326-402 $10^{9}$ celler/l). MR caput ble gjentatt ved én og 15 måneders alder (fig 1). Barnet har senere vist normal psykomotorisk utvikling og er i dag en frisk femåring.
Så langt er det ikke i noe land innført screening av gravide med henblikk på identifisering av HPA-1a-negative eller påvisning av antiHPA-1a-antistoff. Diagnosen føtal/neonatal alloimmun trombocytopeni blir som regel stilt etter utredning av alvorlig trombocytopeni og blødning hos et nyfødt barn. Det innebærer at muligheten for forebyggende tiltak er begrenset til svangerskap der kvinnen tidligere har født et barn med denne diagnosen.

Etter vel fire år ble kvinnen gravid med parets barn nummer to. Hun ble da fulgt tett gjennom svangerskapet med jevnlige ultralydkontroller og målinger av anti-HPA-1aantistoffnivå. Hun hadde høye antistoffverdier $i$ første prøve tatt ved 20 ukers graviditet. To uker før forløsningen var anti-HPA1a-antistoffnivået på over 5000 arbitrære enheter $/ \mathrm{ml}$. (Det er vist at et antistoffnivå hos mor på > 300 enheter/ml gir stor sannsynlighet for trombocytopeni hos barnet (7).)

Moren ble forløst med keisersnitt i uke 37. Forlikelige trombocytter var i beredskap i tilfelle alvorlig trombocytopeni eller blødning hos barnet. Trombocyttelling i navlestrengsblod fra den nyfødte viste alvorlig trombocytopeni, med et tromobocyttall på $2 \cdot 10^{9}$ celler/l. HPA-1a-negativt trombocyttkonsentrat ble derfor umiddelbart transfundert til barnet via navlevenekateter, hvorpå konsentrasjonen steg til $57 \cdot 10^{9}$ celler/l. Videre ble det gitt $0,8 \mathrm{~g} / \mathrm{kg}$ immunglobulin intravenøst. Umiddelbart etter fødselen ble det observert multiple, ørsmå petekkiale hudblødninger på abdomen og ekstremitetene. Cerebral ultralyd viste ingen tegn til hjerneblødning, og allmenntilstanden var god. I løpet av de neste seks dagene ble det gitt ytterligere to doser med immunglobulin og to transfusjoner med HPA-1a-negativt trombocyttkonsentrat. Nivået av trombocytter sank aldri under $45 \cdot 10^{9}$ celler/l og lå stabilt over $100 \cdot 10^{9}$ celler/l etter første leveuke.

\section{Diskusjon}

Vi beskriver her de neonatale sykehistoriene til to søsken med diagnosen føtal/neonatal alloimmun trombocytopeni. Hos det første barnet var diagnosen ikke kjent eller mistenkt før fødselen. Det ble behov for uvanlig intensiv og langvarig behandling, og barnet fikk påvist hjerneblødning. I det neste svangerskapet var diagnosen forventet, og mor og barn fikk tett oppfølging før, under og etter fødselen. Her ble forløpet og utfallet et annet. Barn nummer to hadde også alvorlig trombocytopeni ved fødselen, og morens antistoffnivå under svangerskapet var svært høyt. Dette barnet hadde behov for flere transfusjoner med HPA-1bb (forlikelige) trombocytter. Vi mener det er sannsynlig at tidlig forløsning og rask tilførsel av HPA1bb-trombocytter og immunglobulin intravenøst hos barn nummer to forhindret organblødning og bremset trombocyttdestruksjonen, slik at forløpet ble mindre alvorlig.

For barn nummer én var fødselsforløpet 


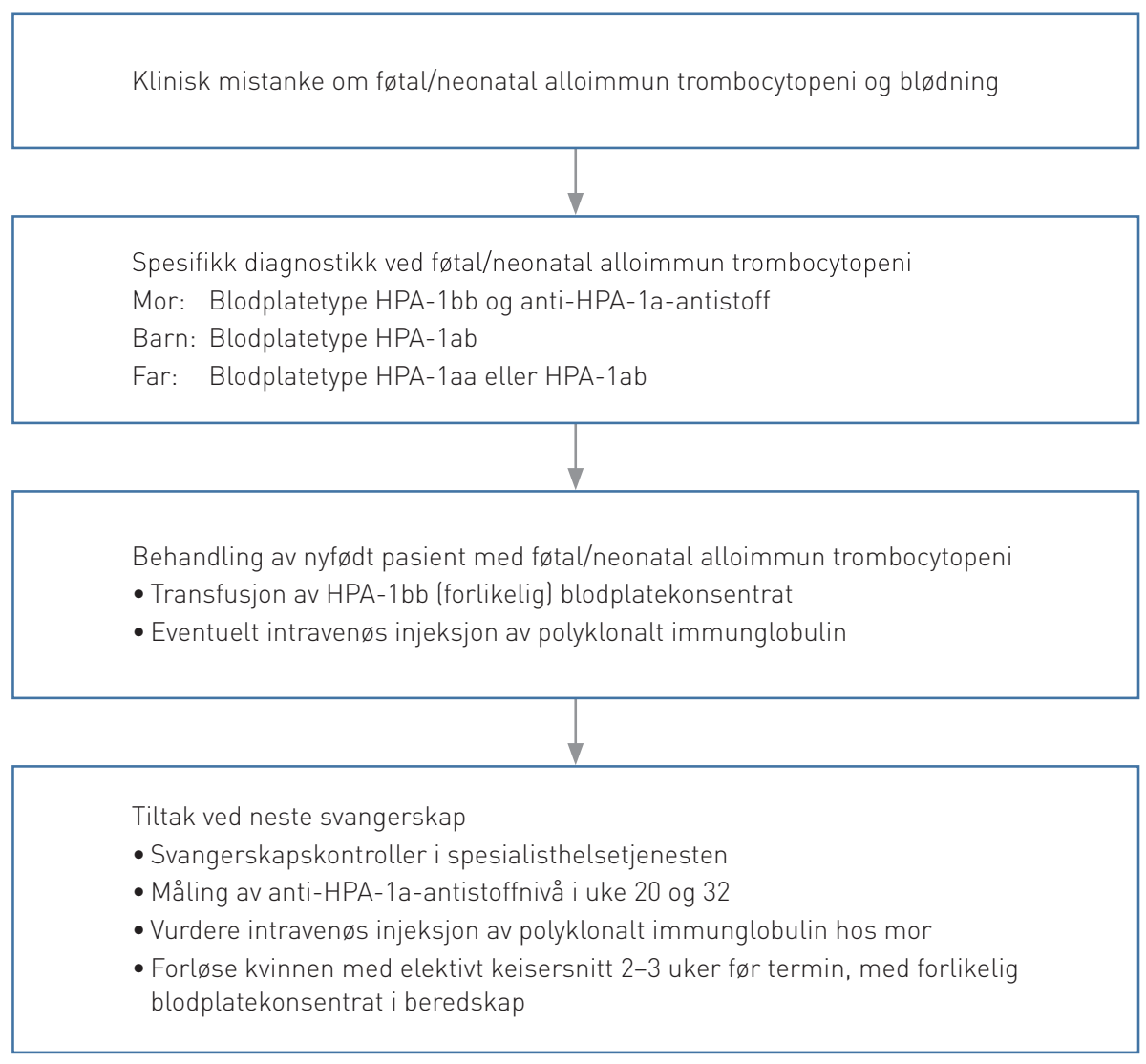

Figur 2 Vårt forslag til diagnostikk, behandling og videre oppfølging ved føtal/neonatal alloimmun trombocytopeni

frem til operativ forløsning langtrukkent. Den intrakraniale blødningen var fersk på fødselstidspunktet (fig 1). Man kan stille spørsmålet om hvorvidt dette kunne ha vært unngått dersom man hadde kjent til morens trombocyttype og antistoffnivå i svangerskapet og utført keisersnitt 2-3 uker før termin med forlikelige trombocytter i beredskap til barnet.

Det kliniske forløpet ved føtal/neonatal alloimmun trombocytopeni er svært varierende og spenner fra lett redusert trombocyttall med spontan normalisering til alvorlig trombocytopeni med intrakranial blødning og neonatal død. I flere studier er det vist sammenheng mellom antistoffnivået hos moren og trombocyttallet hos barnet ( 7 , 9). I tillegg er det vist at behandling av moren før fødselen med intravenøs injeksjon av polyklonalt immunglobulin og steroider reduserer forekomsten av hjerneblødninger $(9,10)$.

Internasjonalt praktiseres ulike tilnærminger ved kjent risiko for føtal/neonatal alloimmun trombocytopeni. Tidligere ble føtal blodprøvekontroll (trombocyttelling) og føtale trombocyttransfusjoner utført, men dette gjøres som hovedregel ikke i dag fordi prosedyren gir stor risiko for blødningskomplikasjoner (11). I Norge er det per i dag sjelden at moren behandles med intraven $\varnothing \mathrm{s}$ injeksjon av polyklonalt immunglobulin før fødselen, men vi mener det er sannsynlig at dette i fremtiden vil bli anbefalt som standardbehandling hos kvinner som tidligere har født barn med hjerneblødning indusert av føtal/neonatal alloimmun trombocytopeni. Det bør uansett tilbys spesiell oppfølging i senere svangerskap dersom en kvinne har født et barn med denne tilstanden. Slik oppfølging bør etter vår oppfatning bestå av gjentatte analyser og kvantifisering av antiHPA-1a-trombocyttantistoff samt anbefaling om elektivt keisersnitt 2-3 uker før termin, med HPA-1bb-trombocytter i beredskap (fig 2). Alternativt kan man gi trombocytter fra tilfeldige givere kombinert med intravenøs injeksjon av polyklonalt immunglobulin inntil HPA-1bb-trombocytter kan skaffes til veie.

Det pågår en nasjonal og internasjonal debatt om screening og rutiner for forebygging/behandling (12-15). Helsedirektoratet satte i 2008 ned en arbeidsgruppe som skulle vurdere screening for føtal/neonatal alloimmun trombocytopeni. Gruppen gikk ikke inn for innføring av dette, men anbefalte at forskning omkring temaet ble videreført (16). Det foreligger nå planer for å prøve ut profylakse mot immunisering $(17,18)$. Innføring av slik profylakse vil kreve HPA-1typing av alle gravide for å identifisere behandlingskandidatene. I tillegg pågår forskning med tanke på å ufarliggjøre antistoffer hos allerede immuniserte mødre (19).

De to sykehistoriene illustrerer at føtal/ neonatal alloimmun trombocytopeni er en alvorlig tilstand som kan opptre i første svangerskap, men hvor muligheten for planlegging av forløsning og neonatal behandling ikke omfatter førstefødte. Korrekt neonatal behandling krever kjennskap til diagnosen for å forhindre komplikasjoner eller begrense dem. Pågående nasjonale og internasjonale studier vil kunne føre til endring i dagens strategi for påvisning, oppfølging og behandling ved føtal/neonatal alloimmun trombocytopeni.

Pasientenes foresatte har gitt samtykke til at artikkelen blir publisert.

\section{Beate Horsberg Eriksen (f. 1969)}

er overlege og spesialist i barnesykdommer, med spesiell interesse innenfor neonatologi og kardiologi. Hun er stipendiat ved Institutt for sirkulasjon og bildediagnostikk, Norges teknisk-naturvitenskapelige universitet. Forfatter har fylt ut ICMJE-skjemaet og oppgir ingen interessekonflikter.

\section{Anne Husebekk (f. 1955)}

er overlege og professor i immunologi, med føtal og neonatal alloimmun trombocytopeni som hovedforskningsfelt.

Forfatter har fylt ut ICMJE-skjemaet og oppgir ingen interessekonflikter. 


\section{Drude Fugelseth (f. 1951)}

er overlege og professor i nyfødtmedisin, med nyfødtsirkulasjon som hovedforskningsfelt. Hun er nestleder ved Institutt for klinisk medisin. Forfatter har fylt ut ICMJE-skjemaet og oppgir ingen interessekonflikter.

\section{Karen Reistad Salberg (f. 1967)}

er spesialist i radiologi og overlege.

Forfatter har fylt ut ICMJE-skjemaet og oppgir ingen interessekonflikter.

\section{Rolf Lindemann (1942-2012)}

var overlege, dr.med. og spesialist i barnesykdommer. Han arbeidet som neonatolog fra 1976, først ved Barneklinikken ved Rikshospitalet og fra 1979 ved Barneavdelingen, Ullevål sykehus. Han var tilknyttet Universitetet i Oslo fra 2001.

\footnotetext{
Litteratur

1. Dreyfus M, Kaplan C, Verdy E et al. Frequency of immune thrombocytopenia in newborns: a prospective study. Blood 1997; 89: 4402-6.

2. Castle V, Andrew M, Kelton J et al. Frequency and mechanism of neonatal thrombocytopenia. J Pediatr 1986; 108: 749-55.

3. Sainio S, Järvenpää AL, Renlund M et al. Thrombo-
}

cytopenia in term infants: a population-based study. Obstet Gynecol 2000; 95: 441-6.

4. Husebekk A, Skogen B. Maternelle alloantistoffers betydning ved trombocytopeni hos nyfødte. Tidsskr Nor Lægeforen 2001: 121:3160-2.

5. Blanchette VS, Johnson J, Rand M. The management of alloimmune neonatal thrombocytopenia. Best Pract Res Clin Haematol 2000; 13: 365-90.

6. Lindemann R, Svenningsen L, Kjeldsen-Kragh J et al. Tre spesielle graviditetsforløp til ettertanke. Tidsskr Nor Lægeforen 2004; 124: 2244-6.

7. Killie MK, Husebekk A, Kjeldsen-Kragh J et al. A prospective study of maternal anti-HPA 1a antibody level as a potential predictor of alloimmune thrombocytopenia in the newborn. Haematologica 2008; 93: 870-7.

8. Kjeldsen-Kragh J, Killie MK, Tomter $\mathrm{G}$ et al. A screening and intervention program aimed to reduce mortality and serious morbidity associated with severe neonatal alloimmune thrombocytopenia. Blood 2007; 110: 833-9.

9. Bertrand G, Drame M, Martageix C et al. Prediction of the fetal status in noninvasive management of alloimmune thrombocytopenia. Blood 2011; 117 : $3209-13$

10. Kamphuis MM, Oepkes D. Fetal and neonatal alloimmune thrombocytopenia: prenatal interventions. Prenat Diagn 2011; 31: 712-9.

11. Kanhai HH, Porcelijn L, Engelfriet CP et al. Management of alloimmune thrombocytopenia. Vox Sang 2007; 93: 370-85.

12. Symington A, Paes B. Fetal and neonatal alloimmune thrombocytopenia: harvesting the evidence to develop a clinical approach to management. Am J Perinatol 2011; 28: 137-44

13. Mechoulan A, Kaplan C, Muller JY et al. Fetal alloimmune thrombocytopenia: is less invasive antenatal management safe? J Matern Fetal Neonatal Med 2011; 24: 564-7

14. Kamphuis MM, Paridaans N, Porcelijn L et al. Screening in pregnancy for fetal or neonatal alloimmune thrombocytopenia: systematic review. BJOG 2010; 117: 1335-43

15. Husebekk A, Killie MK, Kjeldsen-Kragh J et al. Is it time to implement HPA-1 screening in pregnancy? Curr Opin Hematol 2009: 16: 497-502.

16. Anbefalinger vedrørende utvidet nyfødtscreening og screening av gravide for alloimmun trombocytopeni hos fosteret/nyfødte. Oslo: Helsedirektoratet, 2008

17. Tiller H, Killie MK, Chen P et al. Toward a prophylaxis against fetal and neonatal alloimmune thrombocytopenia: induction of antibody-mediated immune suppression and prevention of severe clinical complications in a murine model. Transfusion 2012; 52: 1446-57.

18. Bakchoul T, Boylan B, Sachs UJ et al. Blockade of maternal anti-HPA-1a-mediated platelet clearance by an HPA-1a epitope-specific F(ab') in an in vivo mouse model of alloimmune thrombocytopenia. Transfusion 2009; 49: 265-70.

19. Ghevaert C, Wilcox DA, Fang J et al. Developing recombinant HPA-1a-specific antibodies with abrogated Fcgamma receptor binding for the treatment of fetomaternal alloimmune thrombocytopenia. J Clin Invest 2008; 118: 2929-38.

Mottatt 10.9. 2012, første revisjon innsendt 9.1. 2013, godkjent 24.1. 2013. Medisinsk redaktør Vegard Bruun Wyller.

\section{Kommentar}

\section{Tid for omkamp om screening?}

Beate Horsberg Eriksen og medarbeidere beskriver to søsken med diagnosen føtal/neonatal alloimmun trombocytopeni (FNAIT). Sykdommen er betinget i blodplateuforlikelighet mellom mor og barn og forårsakes av en antistoffmediert destruksjon av fosterets blodplater.

Den første pasienten hadde utbredte petekkiale hudblødninger og grav trombocytopeni ved fødselstidspunktet. Det ble ved MRundersøkelse påvist multiple intrakraniale blødninger, sannsynligvis oppstått i eller nær fødselstidspunktet. I det påfølgende svangerskapet var risikoen for føtal/neonatal alloimmun trombocytopeni erkjent og medisinske tiltak ble iverksatt. Også dette barnet hadde grav trombocytopeni ved fødselen, men unngikk komplikasjoner.

Spørsmålet som reises er i hvilken grad den medisinske håndteringen av de to svangerskapene var utslagsgivende for forskjellen i klinisk utfall. Kunne hjerneblødningen til førstemann vært unngått dersom moren hadde vært screenet for føtal/neonatal alloimmun trombocytopeni?

Screeningdebatten skjøt for alvor fart da resultatene fra den store norske prospektive intervensjonsstudien ble presentert for vel fem år siden (1). Studien inkluderte mer enn 100000 svangerskap fra Nord-Norge og Østlandet, og man benyttet blodplatetyping og antistoffunders $\varnothing$ kelser til å identifisere de $0,2 \%$ av alle svangerskap der det forelå risiko for føtal/neonatal alloimmun trombocytopeni. Denne undergruppen av gravide ble tilbudt medisinsk intervensjon i form av elektiv keisersnittsforløsning ca. 2-4 uker før termin. Forlikelig trombocyttkonsentrat ble gjort tilgjengelig før fødselen i fall det skulle bli nødvendig med tidlig transfusjon av den nyfødte. Man rapporterte en reduksjon i forekomsten av død eller alvorlige intrakraniale blødninger hos barna på $75 \%$, sammenholdt med historiske kontrollbarn (1). Forskergruppen publiserte også analyser som indikerte at intervensjonsprogrammet var samfunnsøkonomisk kostnadssvarende hvis utgiftene som følger av å ta hånd om barn med alvorlig cerebral skade etter hjerneblødning ble tatt med (2).

Hvorfor ble det da ikke umiddelbart allmenn tilslutning til screening for føtal/ neonatal alloimmun trombocytopeni? På tross av de norske forskningsresultatene forble stridsspørsmålet dette: Screening kunne bare rettferdiggjøres dersom mulighetene for medisinsk intervensjon i vesentlig grad reduserte risikoen for blødningskomplikasjoner hos de affiserte fostrene. Det ble vist til observasjonsstudier som indikerte at flertallet av de intrakraniale blødningene ved føtal/neonatal alloimmun trombocytopeni oppstår før 36. svangerskapsuke og dermed likevel ikke vil kunne forebygges ved fremskyndet forløsning (3). Dokumentasjonen på at keisersnitt var tryggere som forløsningsmetode enn vaginal fødsel ble likeledes debattert (4). Helsedirektoratet betonet også i sin rapport de emosjonelle ulempene for HPA-1a-negative gravide som ved screening ble gjort oppmerksomme på risikoen for føtal/neonatal alloimmun trombocytopeni, men der man likevel ikke kunne garantere et komplikasjonsfritt forløp (4).

Helsedirektoratet etterlyste i sin rapport fra 2008 mer forskning på området. Kanskje er det allerede nå på trappene? Den norske forskningsgruppen omkring føtal/neonatal 